\title{
Beyond mineralisation: metabolic functions for matrix mineralisation regulators
}

\author{
Fiona Roberts, Greg Markby, Scott Dillon, Colin Farquharson and Vicky E MacRae \\ Functional Genetics and Development, The Roslin Institute, The University of Edinburgh, Edinburgh, UK \\ Correspondence should be addressed to F Roberts: Fiona.roberts@sund.ku.dk
}

C Farquharson is co-Editor-in-Chief of Journal of Endocrinology. He was not involved in the review or editorial process for this paper, on which he is listed as an author

\begin{abstract}
The physiological mineralisation of skeletal tissues, as well as the pathological mineralisation of soft tissues involves a fine balance between regulators that either promote or inhibit the process. In recent years, several studies have advocated a nonskeletal role for some of these mineralisation regulators in a range of human diseases, including diabetes, cardiovascular disease, obesity and neurodegenerative disease. This is an emerging area of interest and the functional roles and mechanisms of action of these various endocrine factors, phosphatases and phosphodiesterase's in important pathologies are the focus of this review. Mechanistic insight of the pathways through which these acknowledged regulators of skeletal mineralisation act beyond the skeleton has the potential to identify druggable targets for commonly experienced morbidities, notably those related to metabolism and metabolic syndrome.
\end{abstract}
Key Words
- endocrine
- metabolism
- mineralisation
- bone

\section{Introduction}

Bone has numerous classical functions including organ protection, calcium and phosphate ion homeostasis, and facilitation of movement. The skeleton is structurally suited to function: strong and flexible enough to bear load without damage, yet light enough to allow locomotion. Bone is composed of organic constituents including collagenous proteins (principally type I collagen) and non-collagenous proteins (including but not limited to osteocalcin, osteonectin, osteopontin (OPN) and bone sialoprotein (BSP)) (Termine 1988, Roach 1994, Shekaran \& García 2011, Dillon et al. 2019). Bone also contains nonorganic poorly crystalline substituted hydroxyapatite (HA) mineral and water (Glimcher \& Muir 1984, Clarke 2008, Stock 2015). Within bone, a large population of living cells (the osteocytes) are entombed in the mineralised matrix. Bone's material properties are a function of both the relative proportions of these elementary constituents and its structure across length scales, conveying remarkable mechanical properties in a range of contexts from the ear ossicles to the load-bearing bones of the lower limb (Fyhrie 2010, Hart et al. 2017, Schwarcz et al. 2017).

The maintenance of bone quality is critical to facilitate its function (Clarke 2008). To ensure this, there is life-long remodelling of the bone matrix (Kenkre \& Bassett 2018) which involves the coordinated function of two orthologous cell types - the osteoblast (which forms bone) and the osteoclast (which resorbs bone). During bone formation, polarised osteoblasts secrete an extracellular matrix (ECM) which contains a variety of collagenous and non-collagenous proteins, which subsequently mineralises over a period of time. The controlled mineralisation of this osteoid is critical in allowing the anatomically specialised functions of bone. The emergence of sophisticated technologies 
in cell biology, imaging of genetically altered mouse models and mineral phase chemical characterisation has improved our understanding of the fine control of ECM mineralisation during skeletal development and the resultant pathological ramifications.

Both bone formation and bone resorption are energetically costly. This has led to a hypothesis, whereby energy metabolism and bone formation regulate one another in a feedback loop. Following recent work which led to the discovery of metabolically active osteocalcin, a hormone secreted specifically by the osteoblast to promote insulin sensitivity, further evidence has emerged for a metabolic role for bone (Fig. 1) (Lee et al. 2007 Ferron et al. 2010, Clemens \& Karsenty 2011, Wei \& Karsenty 2015). Contemporary research has revealed varied roles for key regulators of ECM mineralisation in a range of physiological and pathophysiological processes. This review will explore these emerging roles.

\section{Classic functions of mineralisation regulators}

Before elaborating on the function of mineralisation regulators beyond the skeleton, we will address the critical role they play in ensuring that bone mineralises physiologically. The mineralisation of bone is dependent upon optimum concentrations of calcium $\left(\mathrm{Ca}^{2+}\right)$ and inorganic phosphate $\left(\mathrm{P}_{\mathrm{i}}\right)$, and the precise mechanism(s) by which mineral is embedded within the collagen fibrils of the ECM is tightly regulated. The regulatory substances include magnesium ions, carbonate, proteoglycans, polyphosphates and poly-phosphorylated molecules and the small integrin-binding ligand, N-linked glycoprotein, non-collagenous proteins (including OPN, BSP, dentin matrix protein, dentin sialophosphoprotein and matrix extracellular phosphogylocprotein) (George et al. 1993, Sodek et al. 1995, Macdougall et al. 1998, Ganss et al. 1999, Qin et al. 2002, 2004, Nampei et al. 2004, Margolis et al. 2014). The mechanisms responsible for the initiation of matrix mineralisation are not fully understood. It has been proposed that the pre-formed extracellular collagen I template mediates mineral nucleation (Christoffersen \& Landis 1991, Landis \& Silver 2009, Nudelman et al. 2013). Others have proposed that matrix vesicles (MVs) control localised accumulation of $\mathrm{Ca}^{2+}$ and $\mathrm{P}_{\mathrm{i}}$ (Anderson, 1969, 1995, Ali et al. 1970). MVs are small (100-300 $\mathrm{nm}$ diameter) extracellular membrane-bound particles released by osteoblasts and chondrocytes. MVs are

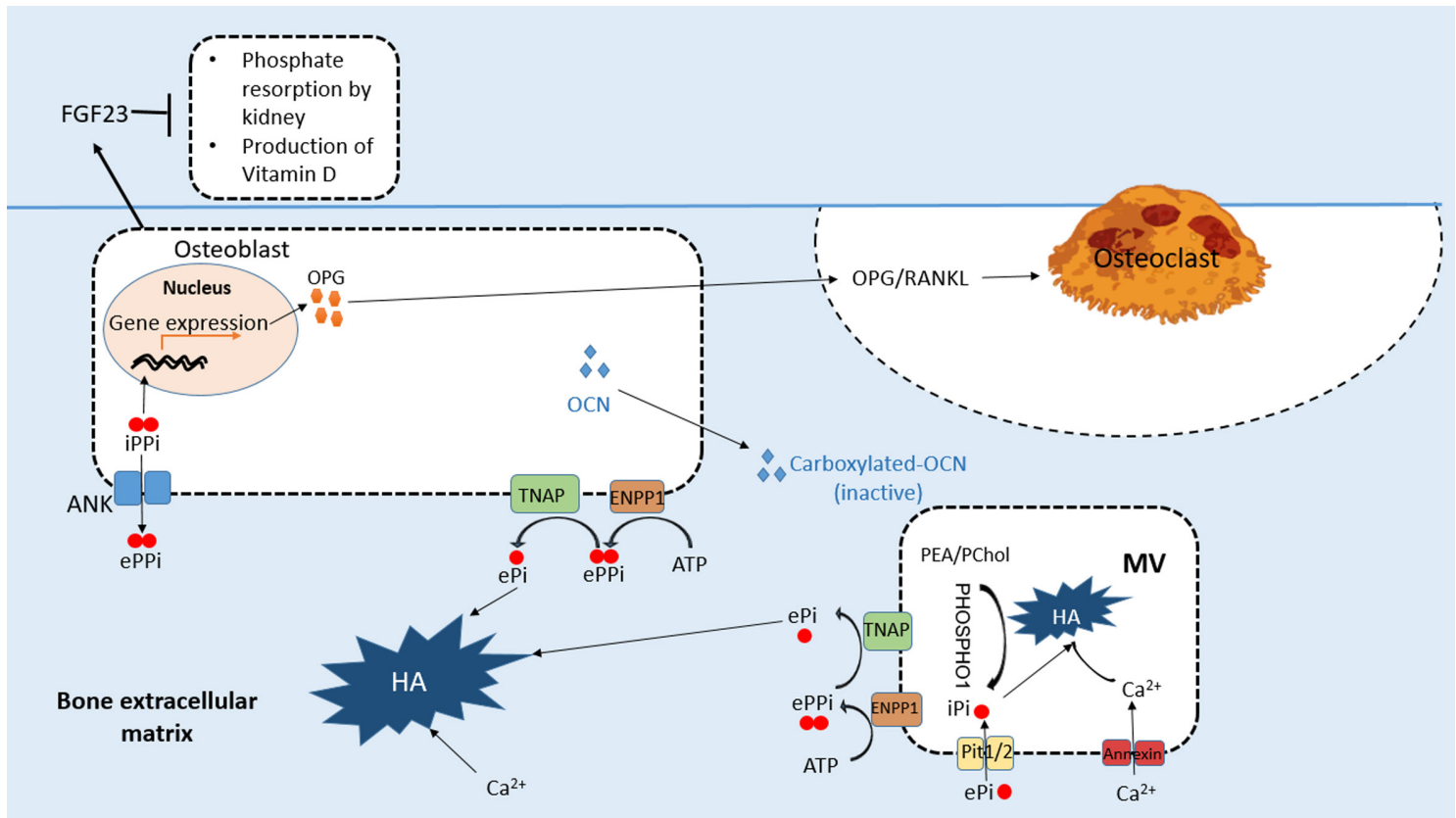

\section{Figure 1}

Schematic representation of matrix mineralisation regulators. The hydroxyapatite (HA) crystals consist of $\mathrm{P}_{\mathrm{i}}$ and $\mathrm{Ca}^{2+}$. In matrix vesicles (MVs), which are secreted by osteoblasts, $\mathrm{P}_{\mathrm{i}}$ accumulates via the actions of PiT1/2 phosphate transporters which shuttle in extracellular $\mathrm{P}_{\mathrm{i}}\left(\mathrm{eP}_{\mathrm{i}}\right)$ from TNAP hydrolysis of $\mathrm{PP}_{\mathrm{i}} \cdot \mathrm{P}_{\mathrm{i}}$ is also generated in MVs by (PHOSPHO1) which hydrolyses phosphomonoesters phosphoethanolamine (PEA) and phosphocholine (PChol) Annexin is responsible for transporting $\mathrm{Ca}^{2+}$ into the MV. ENPP1 generates extracellular $\mathrm{PP}_{\mathrm{i}}\left(\mathrm{ePP}_{\mathrm{i}}\right)$ and this $\mathrm{PP}_{\mathrm{i}}$ is further hydrolysed by TNAP to yield $\mathrm{P}_{\mathrm{i} .}$ ANK transports intracellular $\mathrm{PP}_{\mathrm{i}}\left(\mathrm{iPP}_{\mathrm{j}}\right)$ to the ECM. The iPP $\mathrm{i}_{\mathrm{i}}$ drives the expression of osteopontin, which inhibits HA formation. RANKL promotes osteoclastogenesis and causes the formation of acidic osteoclast resorption lacunae. The acidic $\mathrm{pH}$ drives the formation of metabolically active OCN via de-carboxylation. Metabolically active OCN acts systemically on the adipose tissue skeletal muscle and liver. 
considered to provide a locally protected environment within which $\mathrm{Ca}^{2+}$ and $\mathrm{P}_{\mathrm{i}}$ accumulate in an amorphous state, a process that is regulated by a complex network of pathways (Wuthier \& Lipscomb 2011).

Systemic hormonal regulators of ECM mineralisation include 1,25-dihydroxyvitamin D3, fibroblast growth factor 23 (FGF-23) and parathyroid hormone (PTH). These regulators control $\mathrm{Ca}^{2+}$ and $\mathrm{P}_{\mathrm{i}}$ balance via actions on the intestine and kidney to ensure $\mathrm{Ca}^{2+}$ and $\mathrm{P}_{\mathrm{i}}$ availability for HA formation in bone (Parfitt 1976, Canalis \& Delany 2002, Rowe 2012). Furthermore, the mineralisation process is also mediated by several mineralisation inhibitors. Of notable importance is inorganic pyrophosphate $\left(\mathrm{PP}_{\mathrm{i}}\right)$ which has long been acknowledged as an inhibitor of skeletal mineralisation and regulator of physiological mineralisation (Fleisch et al. 1966). Critically, $\mathrm{PP}_{\mathrm{i}}$ inhibits the growth, dissolution and formation of HA crystals (Fleisch \& Bisaz 1962a,b, Fleisch et al. 1966). Therefore, it is not surprising that many proteins within bone exist to ensure that a $\mathrm{P}_{\mathrm{i}} / \mathrm{PP}_{\mathrm{i}}$ ratio conducive to matrix mineralisation is maintained. This can be understood as a series of highly regulated pathways, which anastomose such that mineral homeostasis is intricately maintained to avoid pathology (Fig. 1).

Ectonucleotide pyrophosphatase phosphodiesterase-1 (ENPP1: EC 3.6.1.9) inhibits mineralisation by the extracellular generation of $\mathrm{PP}_{\mathrm{i}}$ via the hydrolysis of ATP. Encoded by the ankylosis gene (Ank), ANK facilitates the transport of intracellular $\mathrm{PP}_{\mathrm{i}}$ to the extracellular milieu (Ho et al. 2000, Orimo 2010). Deficiency in either ENPP1 or ANK leads to a disruption of the $\mathrm{PP}_{\mathrm{i}} / \mathrm{P}_{\mathrm{i}}$ ratio, resulting in dysregulated pathological mineralisation in humans (Ferreira et al. 2014, Mitton-Fitzgerald et al. 2016). Mice which have a mutated Ank locus and subsequent nonfunctional ANK protein demonstrate a phenotype reflective of the Enpp 1\% mice, with joint ankylosis and concomitantly decreased $\mathrm{PP}_{\mathrm{i}}$ levels (Gurley et al. 2006). Conversely, tissue-nonspecific alkaline phosphatase (TNAP: EC 3.1.3.1), which is anchored within the cell membranes of osteoblasts, chondrocytes and MVs, hydrolyses $\mathrm{PP}_{\mathrm{i}}$ to remove this inhibitor and to generate $\mathrm{P}_{\mathrm{i}}$ and thus promote HA formation (Johnson et al. 2000, Hessle et al. 2002, Harmey et al. 2004, Ciancaglini et al. 2010). The importance of TNAP for skeletal mineralisation is demonstrated in conditions where inactivating mutations in the gene encoding TNAP are present. Hypophosphatasia is associated with decreased enzymatic function and increased $\mathrm{PP}_{\mathrm{i}}$ levels resulting in rickets, osteomalacia and hypomineralised teeth (Whyte et al. 1979, 2015, Anderson et al. 1997b, Mornet 2000,
Mumm et al. 2001, van den Bos et al. 2005, Linglart \& Biosse-Duplan, 2016). Global Akp2 knockout mice present with elevated urinary $\mathrm{PP}_{\mathrm{i}}$ levels and recapitulate the bone mineralisation abnormalities noted in patients with hypophosphatasia (Narisawa et al. 1997, Fedde et al. 1999) TNAP also regulates ectopic calcification (Narisawa et al. 1997, Fedde et al. 1999, Anderson et al. 2004). Increased TNAP activity in the vasculature is associated with medial vascular calcification, vascular stiffness and resultant heart failure (Sheen et al. 2015).

Orphan phosphatase 1 (PHOSPHO1; EC 3.1.3.75) is also responsible for generating $P_{i}$ to facilitate skeletal mineralisation through its highly specific phosphatase activity (Roberts et al. 2007, Dillon et al. 2019). Present within the lumen of the MV, PHOSHPO1 exhibits high specificity for phosphocholine (PCho) and phosphoethanolamine (PEA), which it cleaves to generate intra-vesicular $\mathrm{P}_{\mathrm{i}}$ (Houston et al. 1999, Stewart et al. 2006, Roberts et al. 2007). In addition, the sodium/phosphate co-transporter type III ( (it $_{1}$ ) is hypothesised to be responsible for the transport of $\mathrm{P}_{\mathrm{i}}$ into the $\mathrm{MV}$, while the $\mathrm{Ca}^{2+}$ transport ATPase (Annexin 5) is responsible for the transport of $\mathrm{Ca}^{2+}$ into the MV (Arispe et al. 1996, Kirsch et al. 1997, Nielsen et al. 2001, Yoshiko et al. 2007, Golub 2009, Bourgine et al. 2011).

\section{Metabolic syndrome}

Metabolic syndrome is a global epidemic, with rates increasing alarmingly across both developed and developing countries. Defined by the WHO as a 'pathological condition characterised by abdominal obesity, insulin resistance (IR), hypertension and hyperlipidaemia', the high incidence among the public necessitates action to identify risk factors, causation, intervention and treatment. Metabolic syndrome itself is a cluster of syndromes associated with disrupted metabolic homeostasis (e.g. in chronic caloric excess) (Fig. 2) and can be caused by both environmental and genetic factors (Cornier et al. 2008, Hutcheson \& Rocic 2012, Khan et al. 2015). A seminal study in epigenetics and obesity in twins has revealed that the obesogenic environment is a 'trigger', but not the leading cause of excess weight gain (Bouchard et al. 1990). Indeed, a genetic susceptibility to adipose tissue gain must be present for an individual to develop obesity (Wardle et al. 2008, Silventoinen et al. 2010). Other studies have estimated that the heritability of obesity ranges from $40 \%$ to $70 \%$ (Rose et al. 1998). The incidence of monogenic causes of obesity has been documented 


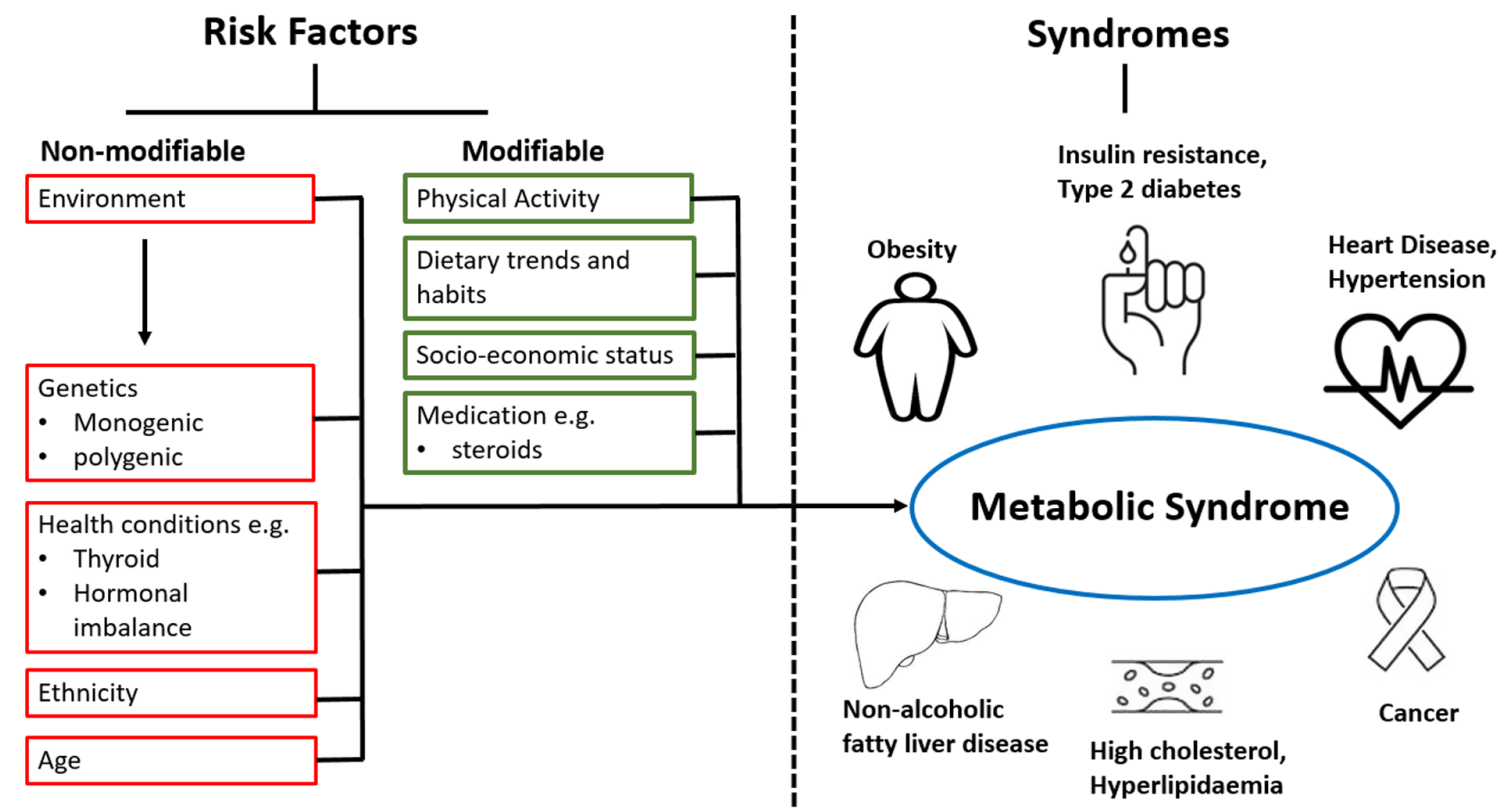

Figure 2

The risk factors and associated syndromes of metabolic syndrome. The risk of developing metabolic syndrome includes non-modifiable and modifiable risk factors. Metabolic syndrome is classically recognised as the concomitant incidence of abdominal obesity, insulin resistance, hypertension and hyperlipidaemia. Metabolic syndrome may include other aetiologies such as cancer, cardiovascular disease and high cholesterol. By its nature, metabolic syndrome is a cluster of various syndromes and so the aetiology is variable between individuals.

over the last 30 years, with over 20 single gene mutations resulting in obesity discovered to date (O'Rahilly 2009). Although the scientific community through the utilisation of contemporary genetic tools, including whole-genome linkage analysis, will undoubtedly identify additional genetic factors contributing to the risk of metabolic syndrome, there is now an emerging body of evidence documenting the ability of bone proteins historically associated with the mineralisation process to impact whole-body energy metabolism. This text will now review these emerging roles in previously unanticipated fields including cardiovascular health and metabolic syndrome.

\section{Ectonucleotide pyrophosphatase/ phosphodiesterase-1 and insulin resistance}

The enzyme ENPP1 (NPP1 in mice) is recognised as a pathogenic factor for IR (Abate et al. 2003), a major feature for patients with type 2 diabetes mellitus (T2DM). The expression levels of ENPP1 are reported to be elevated in muscle and fat of insulin-resistant humans (Maddux et al. 1995). Furthermore, overexpression of ENPP1 is reported to negatively affect the downstream action of the insulin receptor in peripheral tissues such as liver, muscle and fat resulting in a decreased responsiveness to insulin (Frittitta et al. 1998, Goldfine et al. 2008, Prudente et al. 2009).

Various mouse models have been generated to delineate the effect of elevated ENPP1 expression and include animals injected with an adenovirus encoding ENPP1 construct and ENPP1 transgenic mice (Dong et al. 2005, Maddux et al. 2006, Pan et al. 2011). In both models, animals exhibited worsening metabolic phenotypes and IR, while transgenic mice further demonstrated overt diabetic phenotypes (Dong et al. 2005, Maddux et al. 2006). Conversely, Enpp1 ablation in mice (Enpp1-/-) results in pronounced resistance to both obesity and IR following high-fat diet feeding (Huesa et al. 2014). As such, Enpp1-/mice are metabolically protected, adding further credence to the pathogenicity of the NPP1 phenotype (Huesa et al. 2014). Specific polymorphisms of ENPP1, including the ENPP1 K121Q mutant, inhibit signalling through the insulin receptor compared to WT mice and present with an increased associated risk of T2DM (Abate et al. 2003). The K121Q mutation is observed in the Asian Indian population at a frequency of $33 \%$ for at least one copy of K121Q (compared to $27 \%$ in the Caucasian population) and is strongly associated with IR (Abate et al. 2003).

The continued identification of individuals who are genetically susceptible to IR, the pre-requisite for T2DM,
(C) 2020 Society for Endocrinology Published by Bioscientifica Ltd. Printed in Great Britain 
will undeniably prove a critical tool in aiding intervention strategies. Further studies are required to understand the exact mechanisms of actions underpinning different polymorphisms of ENPP1, population incidence of polymorphisms and overall susceptibility of population groups to metabolic syndrome. As the liver is the primary source of circulating $\mathrm{PP}_{\mathrm{i}}$, it is plausible that the liver has a critical role in ENPP1's effect on IR (Fig. 3), although to date little is known about the precise mechanisms involved (Rafter 1960, Jansen et al. 2014, Roberts et al. 2019). Further transgenic mouse models will help us uncover the cell-specific contributions of genes that are associated with an increased risk of IR and T2DM.

\section{Progressive ankylosis protein polymorphisms are a risk factor for obesity related traits}

ANK (encoded by the ANKH gene (Ank in mice)) is a multiple-pass transmembrane $\mathrm{PP}_{\mathrm{i}}$ channelling protein, which facilitates the movement of $\mathrm{PP}_{\mathrm{i}}$ through the plasma membrane from the cytoplasm to the ECM (Ho et al. 2000). Having established ENPP1 as a candidate gene for obesity phenotypes, the scientific community have turned their attention towards the 'functional partners' of ENPP1 which include ANK. A seminal study by Malkin and colleagues who investigated the role of $A N K H$ in the heritability of anthropomorphic traits demonstrated that $A N K H$ is associated with both body weight and BMI (Malkin et al. 2006). This initial study of 212 ethnically homogenous nuclear European origin families prompted further investigation into the role of $A N K H$ in the heritability of obesity and adipose tissue metabolism. Genetic analysis of single nucleotide polymorphisms (SNP) revealed that polymorphisms in $A N K H$ has associations with BMI, waist-to-hip circumference ratio and EGF receptor and leptin plasma levels, with an overall conclusion that $A N K H$ may have a generalised effect on adipose tissue physiology (Korostishevsky et al. 2010). These data support the concept that ANK is a critical player in the complex network connecting bone, adipose tissue and $\mathrm{P}_{\mathrm{i}}$ metabolism.

\section{PHOSPHO1 is critical for lipid metabolism}

While the vast majority of research investigating PHOSPHO1 function has focussed on its role in biomineralisation of cartilage, teeth and bone, there is evidence for physiological roles of PHOSPHO1 as a PCho/ PEA phosphatase in other body systems (Dillon et al. 2019). During erythropoiesis, the immature erythroblasts terminally differentiate, undergoing a host of phenotypic and transcriptomic adaptations, and PHOSPHO1 was found to be upregulated during this process (Gautier et al. 2016). Following this, Huang and colleagues found that PHOSPHO1 was critical for proper erythroblast differentiation via its role in PCho metabolism (Huang et al. 2018).

Additional studies have found associations between PHOSPHO1 and disorders of lipid metabolism. Increased methylation at loci within the PHOSPHO1 gene is associated with T2DM risk (Chambers et al. 2015, Dayeh et al. 2016); a phenomenon which was also suggested

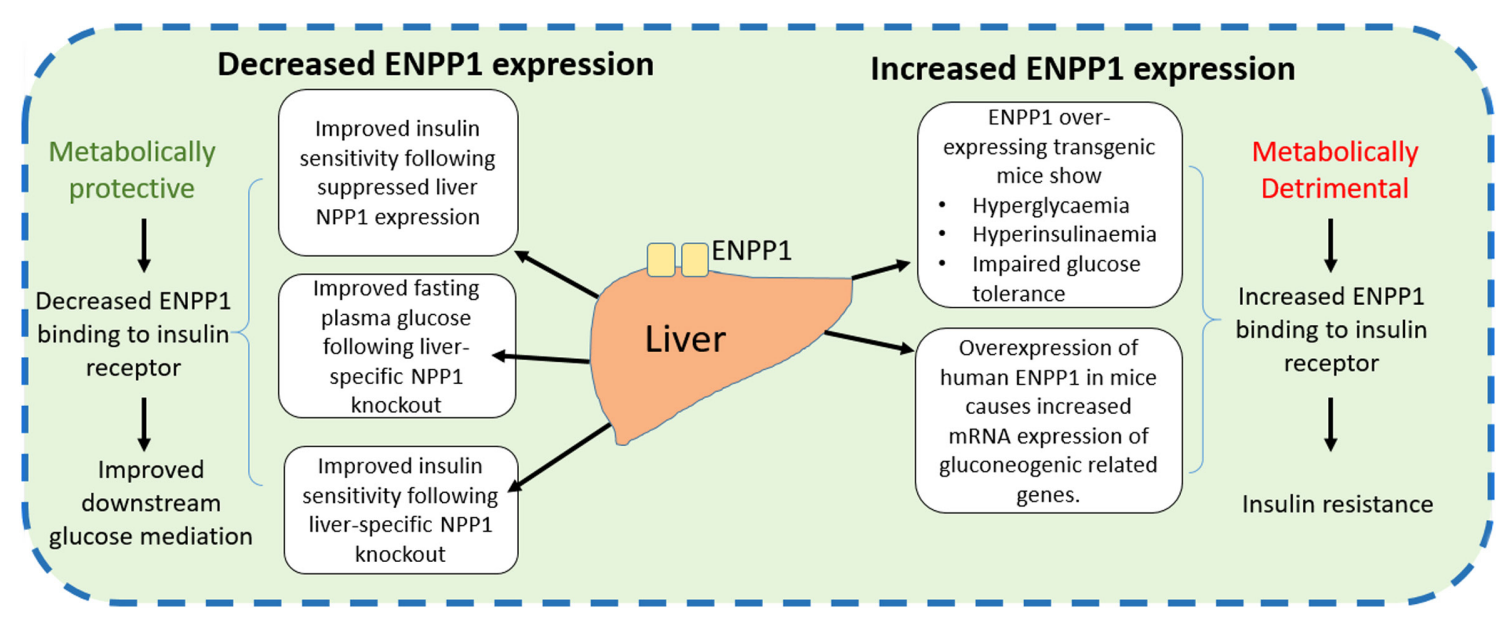

\section{Figure 3}

ENPP1 contributes to insulin resistance and type 2 diabetes mellitus through its actions in the liver. ENPP1 is expressed in the liver and generates PP. The overexpression of ENPP1 leads to metabolically detrimental effects. The decreased expression of ENPP1 is metabolically protective. This has been demonstrated through observations in mouse models and in humans. 
as a potential biomarker for the disease (Willmer et al. 2018). Furthermore, increased methylation of PHOSPHO1 is related to increased high-density lipoprotein in serum (Dayeh et al. 2016, Sayols-Baixeras et al. 2016), while a SNP was found to be significantly associated with risk of clinical measures of obesity (Wu et al. 2018). Although the specific mechanisms at play remain unknown, much evidence suggests that PHOSPHO1 is critical for lipid metabolism in health and disease. These studies indicate a promising avenue for future research to explore these functions in a host of physiological systems outside of bone.

\section{Tissue-nonspecific alkaline phosphatase as a potential therapeutic target for inflammation and diabetes}

The first published identification of ALP dates back to almost 100 years (Robison \& Soames 1924). Continued probing of the non-skeletal functionality of TNAP will undoubtedly reveal previously unexpected roles of this enzyme; indeed, TNAP has been identified to regulate neurogenesis in adults suggesting a critical role for neuronal function (Diaz-Hernandez et al. 2015). These findings demonstrate that Alzheimer's patients have an increased hippocampal TNAP activity and associated increased neuronal death. Furthermore, TNAP is accepted as a regulator of purinergic signalling, hydrolysing ATP and ADP to generate AMP (Moss \& Walli 1969). The role of purinergic signalling in bone was first identified in 1991, following the observation that extracellular ATP is important for osteoblast function and can increase intracellular calcium (Kumagai et al. 1991, Schöfl et al. 1992). Furthermore, purinergic signalling is important in the regulation of inflammatory signalling, whereby enzymatic conversion to AMP aids in the induction of anti-inflammatory responses via adenine receptor associations (Zimmermann 2006). As such, TNAP is proposed to protect against inflammation (Lallès 2014, Peters et al. 2015).

Given that ENPP1 - another critical regulator of purinergic signalling - exhibits notable roles in both bone and energy metabolism, it is plausible to speculate that TNAP will also play a regulatory role in global energy metabolism. The supportive literature on this, however, remains scarce. One large, multiethnic population study in non-diabetic patients with hyperinsulinemia and associated IR reported increased levels of TNAP activity in serum (Cheung et al. 2013).
Morphological and biochemical features of obesity have also been associated with polymorphisms in the TNAP gene (Korostishevsky et al. 2010). In vitro investigations reflect these associations, whereby TNAP expression was higher in cultured osteoblasts like cells in the presence of elevated glucose and insulin levels (Cunha et al. 2014). Given that the aetiology of diabetes includes retinopathy, the TNAP expression within the retina in animal models of diabetes has also been studied (Kantor et al. 2015). Rat models of diabetes demonstrate decreased brainspecific TNAP activity, indicating a neurological role of TNAP. This supports the notion that TNAP is important for brain (neuronal) functionality, and that TNAP plays multi-factorial roles in the body (Zhao et al. 2013). Further analysis, utilising cell-specific TNAP knockout rodent models, will likely identify pharmacological targets of this 'jack of all trades' alkaline phosphatase.

\section{Receptor activator of nuclear factor-кB ligand plays a role in regulating glucose homeostasis}

Receptor activator of NF- $\mathrm{kB}$ ligand (RANKL) is responsible for the formation and activation of osteoclasts by binding to its cognate receptor RANK, conversely, osteoprotegrin (OPG) inhibits osteoclastogenesis (Anderson et al. 1997a, Lacey et al. 1998, Suda et al. 1999, Tong et al. 2019). The administration of neutralising antibodies against RANKL (Denosumab) results in improved bone strength in postmenopausal osteoporotic patients due to an inhibition of osteoclast formation and activity.

RANK regulates glucose homeostasis. In mice with a liver-specific inhibition of RANK activity there is prevention of diet-induced glucose intolerance (Kiechl et al. 2013). On the other hand, the stimulation of NF-kB pathways in liver cells exposed to RANKL resulted in the increased expression of pro-inflammatory genes - a phenomenon associated with hepatic IR and disturbed glucose homoeostasis (Bonnet et al. 2019). In addition, transgenic mice with a high expression of RANKL in the soleus muscle present with muscular alterations including decreased glucose uptake (Bonnet et al. 2019). The work by Kiechl and colleagues revealed that RANKL may be used as a risk predictor of T2DM (Kiechl et al. 2013). They reported that increased expression of RANK likely results in increased activation of the NF- $\mathrm{kB}$ and thus increased systemic and liver-specific inflammatory signalling pathways (Kiechl et al. 2013). The molecular mechanisms which govern this action are unclear, but such events are key to the development of hepatic IR and pancreatic 
$\beta$-cell dysfunction. The increasing evidence of a role for RANKL signalling in the pathogenesis of T2DM may lead to the development of novel pharmacological strategies.

\section{Fibroblast growth factor 23 regulates matrix mineralisation and is associated with important pathologies and mortality}

The hormone FGF23 is one of the three endocrine FGF's, which also includes FGF19 and FGF21 (Angelin et al. 2012, Richter \& Faul 2018). FGF23 is secreted by osteoblasts and osteocytes and plays a critical role in ion mineral homeostasis. The importance of FGF23 for bone health was initially recognised when assessing human genetic and acquired rachitic disease (Liu et al. 2008).

FGF23's is a phosphotonin and its classical role is to promote phosphaturia by increasing Pi excretion via the kidney (Shimada et al. 2004a,b, 2005, Ben-Dov et al. 2007, Olauson et al. 2013, Richter \& Faul 2018, Vervloet 2019). FGF23 signals through the FGF receptor 1 (FGFR1) together with a scaffolding protein named Klotho, which can be membrane-bound or soluble/circulating (Matsumura et al. 1998, Chen et al. 2007, Hu et al. 2016, Richter \& Faul 2018, Vervloet 2019). This action promotes Ras/mitogen-activated protein kinase (MAPK) signalling and subsequent changes in tissue-specific gene expression, which includes the downregulation of PTH and sodiumdependent phosphate transporter (NaPi-2a\&c) expression (Shimada et al. 2004a,b, Ben-Dov et al. 2007, Olauson et al. 2013, Richter \& Faul 2018).

There is growing knowledge of the role of FGF23 outside the regulation of mineral homeostasis and bone health with signal transduction observed in a variety of cell types including hepatocytes, immune cells (macrophages and neutrophils) and cardiac cells (myocytes and cardiac fibroblasts) (Richter \& Faul 2018, Stohr et al. 2018, Vervloet 2019). Elevated FGF23 endocrine signalling in these cell types has predominantly been associated with pathology including left ventricular hypertrophy, heart failure, T2DM, increased risk of infection and chronic kidney disease (CKD) (Faul et al. 2011, Wojcik et al. 2012, Singh et al. 2016, Richter \& Faul 2018, Stohr et al. 2018, Vervloet 2019). In these pathological scenarios, FGF23 signalling through the classical FGFR1 in a Klothodependent manner is a minor route. Instead Klothoindependent signalling primarily occurs through FGFR4 inducing a calcineurin/nuclear factor of activated $\mathrm{T}$ cells (NFAT) signalling cascade (Grabner et al. 2015, Richter \& Faul 2018, Vervloet 2019). This pathological signalling is likely due to increased serum FGF23 and a concomitant decrease of Klotho isoforms. Indeed, this is evident in CKD, where up to a 1000-fold increase in circulating FGF23 has been reported (Isakova et al. 2011, Richter \& Faul 2018, Vervloet 2019).

While many studies have demonstrated an association of FGF23 with several pathologies, it is still poorly understood whether FGF23 plays a causative role in the progression of non-skeletal disease. Understanding the endocrine/molecular mechanisms through which FGF23 elicits its actions will be critical to direct potential future therapeutics. It has been shown in several in vitro studies the damaging effect of Klotho-independent signalling can have on cells, including the promotion of vascular dysfunction, oxidative stress and fibrosis in cardiac cells and induction of inflammatory pathways in hepatocytes (Richter et al. 2016, Singh et al. 2016, Leifheit-Nestler et al. 2018, Richter \& Faul 2018, Millar et al. 2019). As these in vitro studies are unable to mimic the complexity of an organism with multiple tissues involved, it will be critical to know if such FGF23 actions are also observed in humans or animal models. Studies have shown that a reduction in circulating FGF23 levels is associated with better mortality outcomes in humans. However, since FGF23 affects $P_{i}$ levels, it is unclear whether it is the reduction in FGF23 per se that causes these observed improvements (Wetmore et al. 2010, Moe et al. 2015, Sprague et al. 2018, Vervloet 2019).

\section{Conclusion}

The regulators of ECM mineralisation are intrinsic for skeletal formation and maintenance, yet their roles extend to crucial functions beyond mineralisation. Indeed, several studies have reported that mineralisation regulators are associated with a range of conditions including the regulation of metabolism, IR, cardiovascular health and T2DM. These findings suggest that the mechanisms through which bone mineralisation regulators exert their effects, throughout various tissues and their systemic effects, are more complicated and varied than first considered.

This review has provided a concise body of evidence to support the roles of mineralisation regulators beyond the classical functions of bone formation. It is evident that skeletal mineralisation regulators exert systemic effects and are involved in a range of physiological development and pathological conditions. It is likely that increased understanding of the role of mineralisation regulators 
will allow for the development of novel therapeutics for individuals with bone disease and will glean insights into targets for cardiovascular and metabolic pathologies.

\section{Declaration of interest}

The authors declare that there is no conflict of interest that could be perceived as prejudicing the impartiality of this review.

\section{Funding}

F R is supported by PhD studentship funding from Royal (Dick) School of Veterinary Studies, University of Edinburgh. G R M is supported by The Dogs Trust. S D is supported by the Biotechnology and Biological Sciences Research Council (BBSRC) through an EASTBIO Doctoral Training Partnership studentship award (1803936). V E M and C F are supported by funding from the BBSRC in the form of an Institute Strategic Programme Grant (BB/J004316/1).

\section{References}

Abate N, Carulli L, Cabo-Chan Jr A, Chandalia M, Snell PG \& Grundy SM 2003 Genetic polymorphism PC-1 K121Q and ethnic susceptibility to insulin resistance. Journal of Clinical Endocrinology and Metabolism $\mathbf{8 8}$ 5927-5934. (https://doi.org/10.1210/jc.2003-030453)

Ali SY, Sajdera SW \& Anderson HC 1970 Isolation and characterization of calcifying matrix vesicles from epiphyseal cartilage. PNAS $\mathbf{6 7}$ 1513-1520. (https://doi.org/10.1073/pnas.67.3.1513)

Anderson HC 1969 Vesicles associated with calcification in the matrix of epiphyseal cartilage. Journal of Cell Biology 41 59-72. (https://doi. org/10.1083/jcb.41.1.59)

Anderson HC 1995 Molecular biology of matrix vesicles. Clinical Orthopaedics and Related Research 314 266-280. (https://doi. org/10.1097/00003086-199505000-00034)

Anderson DM, Maraskovsky E, Billingsley WL, Dougall WC, Tometsko ME, Roux ER, Teepe MC, DuBose RF, Cosman D \& Galibert L 1997a A homologue of the TNF receptor and its ligand enhance T-cell growth and dendritic-cell function. Nature $\mathbf{3 9 0}$ 175-179. (https://doi.org/10.1038/36593)

Anderson HC, Hsu HH, Morris DC, Fedde KN \& Whyte MP 1997b Matrix vesicles in osteomalacic hypophosphatasia bone contain apatite-like mineral crystals. American Journal of Pathology 151 1555-1561.

Anderson HC, Sipe JB, Hessle L, Dhanyamraju R, Atti E, Camacho NP, Millan JL \& Dhamyamraju R 2004 Impaired calcification around matrix vesicles of growth plate and bone in alkaline phosphatasedeficient mice. American Journal of Pathology 164 841-847. (https:// doi.org/10.1016/s0002-9440(10)63172-0)

Angelin B, Larsson TE \& Rudling M 2012 Circulating fibroblast growth factors as metabolic regulators - a critical appraisal. Cell Metabolism 16 693-705. (https://doi.org/10.1016/j.cmet.2012.11.001)

Arispe N, Rojas E, Genge BR, Wu LN \& Wuthier RE 1996 Similarity in calcium channel activity of annexin $\mathrm{V}$ and matrix vesicles in planar lipid bilayers. Biophysical Journal 71 1764-1775. (https://doi. org/10.1016/S0006-3495(96)79377-3)

Ben-Dov IZ, Galitzer H, Lavi-Moshayoff V, Goetz R, Kuro-o M, Mohammadi M, Sirkis R, Naveh-Many T \& Silver J 2007 The parathyroid is a target organ for FGF23 in rats. Journal of Clinical Investigation 117 4003-4008. (https://doi.org/10.1172/JCI32409)

Bonnet N, Bourgoin L, Biver E, Douni E \& Ferrari S 2019 RANKL inhibition improves muscle strength and insulin sensitivity and restores bone mass. Journal of Clinical Investigation 129 3214-3223. (https://doi.org/10.1172/JCI125915)

Bouchard C, Tremblay A, Despres JP, Nadeau A, Lupien PJ, Theriault G, Dussault J, Moorjani S, Pinault S \& Fournier G 1990 The response to long-term overfeeding in identical twins. New England Journal of Medicine 322 1477-1482. (https://doi.org/10.1056/ NEJM199005243222101)

Bourgine A, Beck L, Beck-Cormier S, Couasnay G, Perre M, Masson M, Khoshniat S, Weiss P \& Guicheux J 2011 Involvement of PiT1 and PiT2 in the response to phosphate in osteoblasts in vitro. Bone 48 S106-S107. (https://doi.org/10.1016/j.bone.2011.03.170)

Canalis E \& Delany AM 2002 Mechanisms of glucocorticoid action in bone. Annals of the New York Academy of Sciences 966 73-81. (https:// doi.org/10.1111/j.1749-6632.2002.tb04204.x)

Chambers JC, Loh M, Lehne B, Drong A, Kriebel J, Motta V, Wahl S, Elliott HR, Rota F, Scott WR, et al. 2015 Epigenome-wide association of DNA methylation markers in peripheral blood from Indian Asians and Europeans with incident type 2 diabetes: a nested case-control study. Lancet: Diabetes and Endocrinology 3 526-534. (https://doi. org/10.1016/S2213-8587(15)00127-8)

Chen CD, Podvin S, Gillespie E, Leeman SE \& Abraham CR 2007 Insulin stimulates the cleavage and release of the extracellular domain of klotho by ADAM10 and ADAM17. PNAS 104 19796-19801. (https:// doi.org/10.1073/pnas.0709805104)

Cheung CL, Tan KC, Lam KS \& Cheung BM 2013 The relationship between glucose metabolism, metabolic syndrome, and bone-specific alkaline phosphatase: a structural equation modeling approach. Journal of Clinical Endocrinology and Metabolism 98 3856-3863. (https://doi.org/10.1210/jc.2013-2024)

Christoffersen J \& Landis WJ 1991 A contribution with review to the description of mineralization of bone and other calcified tissues in vivo. Anatomical Record 230 435-450. (https://doi.org/10.1002/ ar.1092300402)

Ciancaglini P, Yadav MC, Simao AM, Narisawa S, Pizauro JM, Farquharson C, Hoylaerts MF \& Millan JL 2010 Kinetic analysis of substrate utilization by native and TNAP-, NPP1-, or PHOSPHO1deficient matrix vesicles. Journal of Bone and Mineral Research 25 716-723. (https://doi.org/10.1359/jbmr.091023)

Clarke B 2008 Normal bone anatomy and physiology. Clinical Journal of the American Society of Nephrology 3 (Supplement 3) S131-S139. (https://doi.org/10.2215/CJN.04151206)

Clemens TL \& Karsenty G 2011 The osteoblast: an insulin target cell controlling glucose homeostasis. Journal of Bone and Mineral Research 26 677-680. (https://doi.org/10.1002/jbmr.321)

Cornier MA, Dabelea D, Hernandez TL, Lindstrom RC, Steig AJ, Stob NR, Van Pelt RE, Wang H \& Eckel RH 2008 The metabolic syndrome. Endocrine Reviews 29 777-822. (https://doi.org/10.1210/er.2008-0024)

Cunha JS, Ferreira VM, Maquigussa E, Naves MA \& Boim MA 2014 Effects of high glucose and high insulin concentrations on osteoblast function in vitro. Cell and Tissue Research 358 249-256. (https://doi. org/10.1007/s00441-014-1913-x)

Dayeh T, Tuomi T, Almgren P, Perfilyev A, Jansson PA, de Mello VD, Pihlajamaki J, Vaag A, Groop L, Nilsson E, et al. 2016 DNA methylation of loci within ABCG1 and PHOSPHO1 in blood DNA is associated with future type 2 diabetes risk. Epigenetics 11 482-488. (https://doi.org/10.1080/15592294.2016.1178418)

Diaz-Hernandez M, Hernandez F, Miras-Portugal MT \& Avila J 2015 TNAP plays a key role in neural differentiation as well as in neurodegenerative disorders. Sub-Cellular Biochemistry 76 375-385. (https://doi.org/10.1007/978-94-017-7197-9_18)

Dillon S, Staines KA, Millan JL \& Farquharson C 2019 How to build a bone: PHOSPHO1, biomineralization, and beyond. Journal of Bone and Mineral Research Plus 3 e10202. (https://doi.org/10.1002/jbm4.10202)

Dong H, Maddux BA, Altomonte J, Meseck M, Accili D, Terkeltaub R, Johnson K, Youngren JF \& Goldfine ID 2005 Increased hepatic levels of the insulin receptor inhibitor, PC-1/NPP1, induce insulin 
resistance and glucose intolerance. Diabetes 54 367-372. (https://doi. org/10.2337/diabetes.54.2.367)

Faul C, Amaral AP, Oskouei B, Hu MC, Sloan A, Isakova T, Gutierrez OM, Aguillon-Prada R, Lincoln J, Hare JM, et al. 2011 FGF23 induces left ventricular hypertrophy. Journal of Clinical Investigation $\mathbf{1 2 1}$ 4393-4408. (https://doi.org/10.1172/JCI46122)

Fedde KN, Blair L, Silverstein J, Coburn SP, Ryan LM, Weinstein RS, Waymire K, Narisawa S, Millan JL, MacGregor GR, et al. 1999 Alkaline phosphatase knock-out mice recapitulate the metabolic and skeletal defects of infantile hypophosphatasia. Journal of Bone and Mineral Research 14 2015-2026. (https://doi.org/10.1359/ jbmr.1999.14.12.2015)

Ferreira C, Ziegler S \& Gahl WA 2014 Generalized arterial calcification of infancy. In GeneReviews. Eds MP Adam, HH Ardinger, RA Pagon, SE Wallace, LJH Bean, K Stephens \& A Amemiya. Seattle, WA, USA: University of Washington. (available at: https://www.ncbi.nlm.nih. gov/books/NBK253403/)

Ferron M, Wei J, Yoshizawa T, Del Fattore A, DePinho RA, Teti A, Ducy P \& Karsenty G 2010 Insulin signaling in osteoblasts integrates bone remodeling and energy metabolism. Cell 142 296-308. (https://doi. org/10.1016/j.cell.2010.06.003)

Fleisch H \& Bisaz S 1962a Isolation from urine of pyrophosphate, a calcification inhibitor. American Journal of Physiology 203 671-675. (https://doi.org/10.1152/ajplegacy.1962.203.4.671)

Fleisch H \& Bisaz S 1962b Mechanism of calcification: inhibitory role of pyrophosphate. Nature 195 911. (https://doi.org/10.1038/195911a0)

Fleisch H, Russell RG \& Straumann F 1966 Effect of pyrophosphate on hydroxyapatite and its implications in calcium homeostasis. Nature 212 901-903. (https://doi.org/10.1038/212901a0)

Frittitta L, Spampinato D, Solini A, Nosadini R, Goldfine ID, Vigneri R \& Trischitta V 1998 Elevated PC-1 content in cultured skin fibroblasts correlates with decreased in vivo and in vitro insulin action in nondiabetic subjects: evidence that PC-1 may be an intrinsic factor in impaired insulin receptor signaling. Diabetes 47 1095-1100. (https:// doi.org/10.2337/diabetes.47.7.1095)

Fyhrie DP 2010 The mechanical properties of bone. In Osteoporosis in Men, 2nd ed, ch 5, pp 51-67. Eds ES Orwoll, JP Bilezikian \& D Vanderschueren. San Diego, CA, USA: Academic Press.

Ganss B, Kim RH \& Sodek J 1999 Bone sialoprotein. Critical Reviews in Oral Biology and Medicine 10 79-98. (https://doi.org/10.1177/1045441 1990100010401)

Gautier EF, Ducamp S, Leduc M, Salnot V, Guillonneau F, Dussiot M, Hale J, Giarratana MC, Raimbault A, Douay L, et al. 2016 Comprehensive proteomic analysis of human erythropoiesis. Cell Reports 16 1470-1484. (https://doi.org/10.1016/j.celrep.2016.06.085)

George A, Sabsay B, Simonian PA \& Veis A 1993 Characterization of a novel dentin matrix acidic phosphoprotein. Implications for induction of biomineralization. Journal of Biological Chemistry 268 12624-12630.

Glimcher MJ \& Muir H 1984 Recent studies of the mineral phase in bone and its possible linkage to the organic matrix by protein-bound phosphate bonds. Philosophical Transactions of the Royal Society of London Series B 304 479-508. (https://doi.org/10.1098/rstb.1984.0041)

Goldfine ID, Maddux BA, Youngren JF, Reaven G, Accili D, Trischitta V, Vigneri R \& Frittitta L 2008 The role of membrane glycoprotein plasma cell antigen 1/ectonucleotide pyrophosphatase phosphodiesterase 1 in the pathogenesis of insulin resistance and related abnormalities. Endocrine Reviews 29 62-75. (https://doi. org/10.1210/er.2007-0004)

Golub EE 2009 Role of matrix vesicles in biomineralization. Biochimica et Biophysica Acta 1790 1592-1598. (https://doi.org/10.1016/j. bbagen.2009.09.006)

Grabner A, Amaral AP, Schramm K, Singh S, Sloan A, Yanucil C, Li J, Shehadeh LA, Hare JM, David V, et al. 2015 Activation of cardiac fibroblast growth factor receptor 4 causes left ventricular hypertrophy.
Cell Metabolism 22 1020-1032. (https://doi.org/10.1016/j. cmet.2015.09.002)

Gurley KA, Chen H, Guenther C, Nguyen ET, Rountree RB, Schoor M \& Kingsley DM 2006 Mineral formation in joints caused by complete or joint-specific loss of ANK function. Journal of Bone and Mineral Research 21 1238-1247. (https://doi.org/10.1359/jbmr.060515)

Harmey D, Hessle L, Narisawa S, Johnson KA, Terkeltaub R \& Millan JL 2004 Concerted regulation of inorganic pyrophosphate and osteopontin by akp2, enpp1, and ank: an integrated model of the pathogenesis of mineralization disorders. American Journal of Pathology 164 1199-1209. (https://doi.org/10.1016/S0002-9440(10)63208-7)

Hart NH, Nimphius S, Rantalainen T, Ireland A, Siafarikas A \& Newton RU 2017 Mechanical basis of bone strength: influence of bone material, bone structure and muscle action. Journal of Musculoskeletal and Neuronal Interactions 17 114-139.

Hessle L, Johnson KA, Anderson HC, Narisawa S, Sali A, Goding JW, Terkeltaub R \& Millan JL 2002 Tissue-nonspecific alkaline phosphatase and plasma cell membrane glycoprotein-1 are central antagonistic regulators of bone mineralization. PNAS 99 9445-9449. (https://doi.org/10.1073/pnas.142063399)

Ho AM, Johnson MD \& Kingsley DM 2000 Role of the mouse ank gene in control of tissue calcification and arthritis. Science 289 265-270. (https://doi.org/10.1126/science.289.5477.265)

Houston B, Seawright E, Jefferies D, Hoogland E, Lester D, Whitehead C \& Farquharson C 1999 Identification and cloning of a novel phosphatase expressed at high levels in differentiating growth plate chondrocytes. Biochimica et Biophysica Acta 1448 500-506. (https:// doi.org/10.1016/s0167-4889(98)00153-0)

Hu MC, Shi M, Zhang J, Addo T, Cho HJ, Barker SL, Ravikumar P, Gillings N, Bian A, Sidhu SS, et al. 2016 Renal production, uptake, and handling of circulating alphaKlotho. Journal of the American Society of Nephrology 27 79-90. (https://doi.org/10.1681/ASN.2014101030)

Huang NJ, Lin YC, Lin CY, Pishesha N, Lewis CA, Freinkman E, Farquharson C, Millan JL \& Lodish H 2018 Enhanced phosphocholine metabolism is essential for terminal erythropoiesis. Blood $\mathbf{1 3 1}$ 2955-2966. (https://doi.org/10.1182/blood-2018-03-838516)

Huesa C, Zhu D, Glover JD, Ferron M, Karsenty G, Milne EM, Millan JL, Ahmed SF, Farquharson C, Morton NM, et al. 2014 Deficiency of the bone mineralization inhibitor NPP1 protects mice against obesity and diabetes. Disease Models and Mechanisms 7 1341-1350. (https://doi. org/10.1242/dmm.017905)

Hutcheson R \& Rocic P 2012 The metabolic syndrome, oxidative stress, environment, and cardiovascular disease: the great exploration. Experimental Diabetes Research 2012 271028. (https://doi. org/10.1155/2012/271028)

Isakova T, Xie H, Yang W, Xie D, Anderson AH, Scialla J, Wahl P, Gutierrez OM, Steigerwalt S, He J, et al. 2011 Fibroblast growth factor 23 and risks of mortality and end-stage renal disease in patients with chronic kidney disease. JAMA 305 2432-2439. (https://doi. org/10.1001/jama.2011.826)

Jansen RS, Duijst S, Mahakena S, Sommer D, Szeri F, Varadi A, Plomp A, Bergen AA, Oude Elferink RP, Borst P, et al. 2014 ABCC6-mediated ATP secretion by the liver is the main source of the mineralization inhibitor inorganic pyrophosphate in the systemic circulation-brief report. Arteriosclerosis, Thrombosis, and Vascular Biology 34 1985-1989. (https://doi.org/10.1161/ATVBAHA.114.304017)

Johnson KA, Hessle L, Vaingankar S, Wennberg C, Mauro S, Narisawa S, Goding JW, Sano K, Millan JL \& Terkeltaub R 2000 Osteoblast tissue-nonspecific alkaline phosphatase antagonizes and regulates PC-1. American Journal of Physiology: Regulatory, Integrative and Comparative Physiology 279 R1365-R1377. (https://doi.org/10.1152/ ajpregu.2000.279.4.R1365)

Kantor O, Cserpan D, Volgyi B, Lukats Á \& Somogyvari Z 2015 The retinal TNAP. Sub-Cellular Biochemistry 76 107-123. (https://doi. org/10.1007/978-94-017-7197-9_6) https://joe.bioscientifica.com

https://doi.org/10.1530/JOE-19-0460 (c) 2020 Society for Endocrinology Published by Bioscientifica Ltd. Printed in Great Britain 
Kenkre JS \& Bassett J 2018 The bone remodelling cycle. Annals of Clinical Biochemistry 55 308-327. (https://doi. org/10.1177/0004563218759371)

Khan RJ, Gebreab SY, Sims M, Riestra P, Xu R \& Davis SK 2015 Prevalence, associated factors and heritabilities of metabolic syndrome and its individual components in African Americans: the Jackson Heart Study. BMJ Open 5 e008675. (https://doi.org/10.1136/ bmjopen-2015-008675)

Kiechl S, Wittmann J, Giaccari A, Knoflach M, Willeit P, Bozec A, Moschen AR, Muscogiuri G, Sorice GP, Kireva T, et al. 2013 Blockade of receptor activator of nuclear factor-kB (RANKL) signaling improves hepatic insulin resistance and prevents development of diabetes mellitus. Nature Medicine 19 358-363. (https://doi.org/10.1038/ nm.3084)

Kirsch T, Nah HD, Demuth DR, Harrison G, Golub EE, Adams SL \& Pacifici M 1997 Annexin V-mediated calcium flux across membranes is dependent on the lipid composition: implications for cartilage mineralization. Biochemistry 36 3359-3367. (https://doi.org/10.1021/ bi9626867)

Korostishevsky M, Cohen Z, Malkin I, Ermakov S, Yarenchuk O \& Livshits G 2010 Morphological and biochemical features of obesity are associated with mineralization genes' polymorphisms. International Journal of Obesity 34 1308-1318. (https://doi. org/10.1038/ijo.2010.53)

Kumagai H, Sacktor B \& Filburn CR 1991 Purinergic regulation of cytosolic calcium and phosphoinositide metabolism in rat osteoblastlike osteosarcoma cells. Journal of Bone and Mineral Research 6 697-708. (https://doi.org/10.1002/jbmr.5650060707)

Lacey DL, Timms E, Tan HL, Kelley MJ, Dunstan CR, Burgess T, Elliott R, Colombero A, Elliott G, Scully S, et al. 1998 Osteoprotegerin ligand is a cytokine that regulates osteoclast differentiation and activation. Cell 93 165-176. (https://doi.org/10.1016/s0092-8674(00)81569-x)

Lallès JP 2014 Intestinal alkaline phosphatase: novel functions and protective effects. Nutrition Reviews 72 82-94. (https://doi. org/10.1111/nure.12082)

Landis WJ \& Silver FH 2009 Mineral deposition in the extracellular matrices of vertebrate tissues: identification of possible apatite nucleation sites on type I collagen. Cells, Tissues, Organs 189 20-24. (https://doi.org/10.1159/000151454)

Lee NK, Sowa H, Hinoi E, Ferron M, Ahn JD, Confavreux C, Dacquin R, Mee PJ, McKee MD, Jung DY, et al. 2007 Endocrine regulation of energy metabolism by the skeleton. Cell 130 456-469. (https://doi. org/10.1016/j.cell.2007.05.047)

Leifheit-Nestler M, Kirchhoff F, Nespor J, Richter B, Soetje B, Klintschar M, Heineke J \& Haffner D 2018 Fibroblast growth factor 23 is induced by an activated renin-angiotensin-aldosterone system in cardiac myocytes and promotes the pro-fibrotic crosstalk between cardiac myocytes and fibroblasts. Nephrology, Dialysis, Transplantation 33 1722-1734. (https://doi.org/10.1093/ndt/gfy006)

Linglart A \& Biosse-Duplan M 2016 Hypophosphatasia. Current Osteoporosis Reports 14 95-105. (https://doi.org/10.1007/s11914-0160309-0)

Liu S, Zhou J, Tang W, Menard R, Feng JQ \& Quarles LD 2008 Pathogenic role of FGF23 in Dmp1-null mice. American Journal of Physiology: Endocrinology and Metabolism 295 E254-E261. (https://doi org/10.1152/ajpendo.90201.2008)

MacDougall M, Gu TT, Luan X, Simmons D \& Chen J 1998 Identification of a novel isoform of mouse dentin matrix protein 1: spatial expression in mineralized tissues. Journal of Bone and Mineral Research 13 422-431. (https://doi.org/10.1359/jbmr.1998.13.3.422)

Maddux BA, Sbraccia P, Kumakura S, Sasson S, Youngren J, Fisher A, Spencer S, Grupe A, Henzel W \& Stewart TA 1995 Membrane glycoprotein PC-1 and insulin resistance in non-insulindependent diabetes mellitus. Nature 373 448-451. (https://doi. org $/ 10.1038 / 373448 \mathrm{a} 0)$
Maddux BA, Chang YN, Accili D, McGuinness OP, Youngren JF \& Goldfine ID 2006 Overexpression of the insulin receptor inhibitor PC-1/ENPP1 induces insulin resistance and hyperglycemia. American Journal of Physiology: Endocrinology and Metabolism 290 E746-E749. (https://doi.org/10.1152/ajpendo.00298.2005)

Malkin I, Ermakov S, Kobyliansky E \& Livshits G 2006 Strong association between polymorphisms in ANKH locus and skeletal size traits. Human Genetics 120 42-51. (https://doi.org/10.1007/s00439-0060173-6)

Margolis HC, Kwak SY \& Yamazaki H 2014 Role of mineralization inhibitors in the regulation of hard tissue biomineralization: relevance to initial enamel formation and maturation. Frontiers in Physiology 5 339. (https://doi.org/10.3389/fphys.2014.00339)

Matsumura Y, Aizawa H, Shiraki-Iida T, Nagai R, Kuro-o M \& Nabeshima Y 1998 Identification of the human klotho gene and its two transcripts encoding membrane and secreted klotho protein. Biochemical and Biophysical Research Communications 242 626-630. (https://doi.org/10.1006/bbrc.1997.8019)

Millar SA, Anderson SI \& O'Sullivan SE 2019 Osteokines and the vasculature: a review of the in vitro effects of osteocalcin, fibroblast growth factor-23 and lipocalin-2. PeerJ 7 e7139. (https://doi. org/10.7717/peerj.7139)

Mitton-Fitzgerald E, Gohr CM, Bettendorf B \& Rosenthal AK 2016 The role of ANK in calcium pyrophosphate deposition disease. Current Rheumatology Reports 18 25. (https://doi.org/10.1007/s11926-0160574-z)

Moe SM, Chertow GM, Parfrey PS, Kubo Y, Block GA, Correa-Rotter R, Drueke TB, Herzog CA, London GM, Mahaffey KW, et al. 2015 Cinacalcet, fibroblast growth factor-23, and cardiovascular disease in hemodialysis: the evaluation of Cinacalcet $\mathrm{HCl}$ therapy to lower cardiovascular events (EVOLVE) trial. Circulation 132 27-39. (https:// doi.org/10.1161/CIRCULATIONAHA.114.013876)

Mornet E 2000 Hypophosphatasia: the mutations in the tissuenonspecific alkaline phosphatase gene. Human Mutation 15 309-315. (https://doi.org/10.1002/(SICI)1098-1004(200004)15:4<309::AIDHUMU2>3.0.CO;2-C)

Moss DW \& Walli AK 1969 Intermediates in the hydrolysis of ATP by human alkaline phosphatase. Biochimica et Biophysica Acta 191 476-477. (https://doi.org/10.1016/0005-2744(69)90269-1)

Mumm S, Jones J, Finnegan P \& Whyte MP 2001 Hypophosphatasia: molecular diagnosis of Rathbun's original case. Journal of Bone and Mineral Research 16 1724-1727. (https://doi.org/10.1359/ jbmr.2001.16.9.1724)

Nampei A, Hashimoto J, Hayashida K, Tsuboi H, Shi K, Tsuji I, Miyashita H, Yamada T, Matsukawa N, Matsumoto M, et al. 2004 Matrix extracellular phosphoglycoprotein (MEPE) is highly expressed in osteocytes in human bone. Journal of Bone and Mineral Metabolism 22 176-184. (https://doi.org/10.1007/s00774-003-0468-9)

Narisawa S, Frohlander N \& Millan JL 1997 Inactivation of two mouse alkaline phosphatase genes and establishment of a model of infantile hypophosphatasia. Developmental Dynamics 208 432-446. (https://doi.org/10.1002/(SICI)1097-0177(199703)208:3<432::AIDAJA13>3.0.CO;2-1)

Nielsen LB, Pedersen FS \& Pedersen L 2001 Expression of type III sodiumdependent phosphate transporters/retroviral receptors mRNAs during osteoblast differentiation. Bone 28 160-166. (https://doi.org/10.1016/ s8756-3282(00)00418-x)

Nudelman F, Lausch AJ, Sommerdijk NA \& Sone ED 2013 In vitro models of collagen biomineralization. Journal of Structural Biology 183 258-269. (https://doi.org/10.1016/j.jsb.2013.04.003)

Olauson H, Lindberg K, Amin R, Sato T, Jia T, Goetz R, Mohammadi M, Andersson G, Lanske B \& Larsson TE 2013 Parathyroid-specific deletion of klotho unravels a novel calcineurin-dependent FGF23 signaling pathway that regulates PTH secretion. PLoS Genetics 9 e1003975. (https://doi.org/10.1371/journal.pgen.1003975) https://joe.bioscientifica.com https://doi.org/10.1530/JOE-19-0460 (c) 2020 Society for Endocrinology Published by Bioscientifica Ltd. Printed in Great Britain 
O'Rahilly S 2009 Human genetics illuminates the paths to metabolic disease. Nature 462 307-314. (https://doi.org/10.1038/nature08532)

Orimo H 2010 The mechanism of mineralization and the role of alkaline phosphatase in health and disease. Journal of Nippon Medical School $\mathbf{7 7}$ 4-12. (https://doi.org/10.1272/jnms.77.4)

Pan W, Ciociola E, Saraf M, Tumurbaatar B, Tuvdendorj D, Prasad S, Chandalia M \& Abate N 2011 Metabolic consequences of ENPP1 overexpression in adipose tissue. American Journal of Physiology: Endocrinology and Metabolism 301 E901-E911. (https://doi. org/10.1152/ajpendo.00087.2011)

Parfitt AM 1976 The actions of parathyroid hormone on bone: relation to bone remodeling and turnover, calcium homeostasis, and metabolic bone disease. Part I of IV parts: mechanisms of calcium transfer between blood and bone and their cellular basis: morphological and kinetic approaches to bone turnover. Metabolism: Clinical and Experimental 25 809-844. (https://doi.org/10.1016/00260495(76)90151-7)

Peters E, Geraci S, Heemskerk S, Wilmer MJ, Bilos A, Kraenzlin B, Gretz N, Pickkers P \& Masereeuw R 2015 Alkaline phosphatase protects against renal inflammation through dephosphorylation of lipopolysaccharide and adenosine triphosphate. British Journal of Pharmacology 172 4932-4945. (https://doi.org/10.1111/bph.13261)

Prudente S, Morini E \& Trischitta V 2009 Insulin signaling regulating genes: effect on T2DM and cardiovascular risk. Nature Reviews: Endocrinology 5 682-693. (https://doi.org/10.1038/nrendo.2009.215)

Qin C, Brunn JC, Cadena E, Ridall A, Tsujigiwa H, Nagatsuka H, Nagai N \& Butler WT 2002 The expression of dentin sialophosphoprotein gene in bone. Journal of Dental Research 81 392-394. (https://doi. org/10.1177/154405910208100607)

Qin C, Baba O \& Butler WT 2004 Post-translational modifications of sibling proteins and their roles in osteogenesis and dentinogenesis. Critical Reviews in Oral Biology and Medicine 15 126-136. (https://doi. org/10.1177/154411130401500302)

Rafter GW 1960 Pyrophosphate metabolism in liver mitochondria. Journal of Biological Chemistry 235 2475-2477.

Richter B \& Faul C 2018 FGF23 actions on target tissues-with and without klotho. Frontiers in Endocrinology 9 189. (https://doi.org/10.3389/ fendo.2018.00189)

Richter B, Haller J, Haffner D \& Leifheit-Nestler M 2016 Klotho modulates FGF23-mediated NO synthesis and oxidative stress in human coronary artery endothelial cells. Pflugers Archiv 468 1621-1635. (https://doi.org/10.1007/s00424-016-1858-x)

Roach HI 1994 Why does bone matrix contain non-collagenous proteins? The possible roles of osteocalcin, osteonectin, osteopontin and bone sialoprotein in bone mineralisation and resorption. Cell Biology International 18 617-628. (https://doi.org/10.1006/cbir.1994.1088)

Roberts S, Narisawa S, Harmey D, Millan JL \& Farquharson C 2007 Functional involvement of PHOSPHO1 in matrix vesicle-mediated skeletal mineralization. Journal of Bone and Mineral Research 22 617-627. (https://doi.org/10.1359/jbmr.070108)

Roberts F, Zhu D, Farquharson C \& Macrae VE 2019 ENPP1 in the regulation of mineralization and beyond. Trends in Biochemical Sciences 44 616-628. (https://doi.org/10.1016/j.tibs.2019.01.010)

Robison R \& Soames KM 1924 The possible significance of Hexosephosphoric esters in ossification: Part II. The phosphoric esterase of ossifying cartilage. Biochemical Journal 18 740-754. (https://doi.org/10.1042/bj0180740)

Rose KM, Newman B, Mayer-Davis EJ \& Selby JV 1998 Genetic and behavioral determinants of waist-hip ratio and waist circumference in women twins. Obesity Research 6 383-392. (https://doi. org/10.1002/j.1550-8528.1998.tb00369.x)

Rowe PS 2012 Regulation of bone-renal mineral and energy metabolism: the PHEX, FGF23, DMP1, MEPE ASARM pathway. Critical Reviews in Eukaryotic Gene Expression 22 61-86. (https://doi.org/10.1615/ critreveukargeneexpr.v22.11.50)
Sayols-Baixeras S, Subirana I, Lluis-Ganella C, Civeira F, Roquer J, Do AN, Absher D, Cenarro A, Munoz D, Soriano-Tarraga C, et al. 2016 Identification and validation of seven new loci showing differential DNA methylation related to serum lipid profile: an epigenomewide approach. The REGICOR study. Human Molecular Genetics 25 4556-4565. (https://doi.org/10.1093/hmg/ddw285)

Schöfl C, Cuthbertson KS, Walsh CA, Mayne C, Cobbold P, von zur Muhlen A, Hesch RD \& Gallagher JA 1992 Evidence for P2-purinoceptors on human osteoblast-like cells. Journal of Bone and Mineral Research 7 485-491. (https://doi.org/10.1002/ jbmr.5650070504)

Schwarcz HP, Abueidda D \& Jasiuk I 2017 The ultrastructure of bone and its relevance to mechanical properties. Frontiers in Physics 539. (https://doi.org/10.3389/fphy.2017.00039)

Sheen CR, Kuss P, Narisawa S, Yadav MC, Nigro J, Wang W, Chhea TN, Sergienko EA, Kapoor K, Jackson MR, et al. 2015 Pathophysiological role of vascular smooth muscle alkaline phosphatase in medial artery calcification. Journal of Bone and Mineral Research 30 824-836. (https:// doi.org/10.1002/jbmr.2420)

Shekaran A \& García AJ 2011 Extracellular matrix-mimetic adhesive biomaterials for bone repair. Journal of Biomedical Materials Research: Part A 96 261-272. (https://doi.org/10.1002/jbm.a.32979)

Shimada T, Hasegawa H, Yamazaki Y, Muto T, Hino R, Takeuchi Y, Fujita T, Nakahara K, Fukumoto S \& Yamashita T 2004a FGF-23 is a potent regulator of vitamin D metabolism and phosphate homeostasis. Journal of Bone and Mineral Research 19 429-435. (https:// doi.org/10.1359/JBMR.0301264)

Shimada T, Urakawa I, Yamazaki Y, Hasegawa H, Hino R, Yoneya T, Takeuchi Y, Fujita T, Fukumoto S \& Yamashita T 2004b FGF-23 transgenic mice demonstrate hypophosphatemic rickets with reduced expression of sodium phosphate cotransporter type IIa. Biochemical and Biophysical Research Communications 314 409-414. (https://doi. org/10.1016/j.bbrc.2003.12.102)

Shimada T, Yamazaki Y, Takahashi M, Hasegawa H, Urakawa I, Oshima T, Ono K, Kakitani M, Tomizuka K, Fujita T, et al. 2005 Vitamin D receptor-independent FGF23 actions in regulating phosphate and vitamin D metabolism. American Journal of Physiology: Renal Physiology 289 F1088-F1095. (https://doi.org/10.1152/ajprenal.00474.2004)

Silventoinen K, Rokholm B, Kaprio J \& Sorensen TI 2010 The genetic and environmental influences on childhood obesity: a systematic review of twin and adoption studies. International Journal of Obesity 34 29-40. (https://doi.org/10.1038/ijo.2009.177)

Singh S, Grabner A, Yanucil C, Schramm K, Czaya B, Krick S, Czaja MJ, Bartz R, Abraham R, Di Marco GS, et al. 2016 Fibroblast growth factor 23 directly targets hepatocytes to promote inflammation in chronic kidney disease. Kidney International 90 985-996. (https://doi. org/10.1016/j.kint.2016.05.019)

Sodek J, Chen J, Nagata T, Kasugai S, Todescan Jr R, Li IW \& Kim RH 1995 Regulation of osteopontin expression in osteoblasts. Annals of the New York Academy of Sciences 760 223-241. (https://doi. org/10.1111/j.1749-6632.1995.tb44633.x)

Sprague SM, Ketteler M, Covic AC, Floege J, Rakov V, Walpen S \& Rastogi A 2018 Long-term efficacy and safety of sucroferric oxyhydroxide in African American dialysis patients. Hemodialysis International: International Symposium on Home Hemodialysis $\mathbf{2 2}$ 480-491. (https://doi.org/10.1111/hdi.12663)

Stewart AJ, Roberts SJ, Seawright E, Davey MG, Fleming RH \& Farquharson C 2006 The presence of PHOSPHO1 in matrix vesicles and its developmental expression prior to skeletal mineralization. Bone 39 1000-1007. (https://doi.org/10.1016/j.bone.2006.05.014)

Stock SR 2015 The mineral-collagen interface in bone. Calcified Tissue International 97 262-280. (https://doi.org/10.1007/s00223-0159984-6)

Stohr R, Schuh A, Heine GH \& Brandenburg V 2018 FGF23 in cardiovascular disease: innocent bystander or active mediator? https://joe.bioscientifica.com

https://doi.org/10.1530/JOE-19-0460
(C) 2020 Society for Endocrinology Published by Bioscientifica Ltd. Printed in Great Britain 
Frontiers in Endocrinology 9 351. (https://doi.org/10.3389/ fendo.2018.00351)

Suda T, Takahashi N, Udagawa N, Jimi E, Gillespie MT \& Martin TJ 1999 Modulation of osteoclast differentiation and function by the new members of the tumor necrosis factor receptor and ligand families. Endocrine Reviews 20 345-357. (https://doi.org/10.1210/ edrv.20.3.0367)

Termine JD 1988 Non-collagen proteins in bone. Ciba Foundation Symposium 136 178-202. (https://doi.org/10.1002/9780470513637.ch12)

Tong X, Gu J, Song R, Wang D, Sun Z, Sui C, Zhang C, Liu X, Bian J \& Liu Z 2019 Osteoprotegerin inhibit osteoclast differentiation and bone resorption by enhancing autophagy via AMPK/mTOR/p70S6K signaling pathway in vitro. Journal of Cellular Biochemistry 120 1630-1642. (https://doi.org/10.1002/jcb.27468)

van den Bos T, Handoko G, Niehof A, Ryan LM, Coburn SP, Whyte MP \& Beertsen W 2005 Cementum and dentin in hypophosphatasia. Journal of Dental Research 84 1021-1025. (https://doi. org/10.1177/154405910508401110)

Vervloet M 2019 Renal and extrarenal effects of fibroblast growth factor 23. Nature Reviews: Nephrology 15 109-120. (https://doi.org/10.1038/ s41581-018-0087-2)

Wardle J, Carnell S, Haworth CM \& Plomin R 2008 Evidence for a strong genetic influence on childhood adiposity despite the force of the obesogenic environment. American Journal of Clinical Nutrition $\mathbf{8 7}$ 398-404. (https://doi.org/10.1093/ajcn/87.2.398)

Wei J \& Karsenty G 2015 An overview of the metabolic functions of osteocalcin. Current Osteoporosis Reports 13 180-185. (https://doi. org/10.1007/s11914-015-0267-y)

Wetmore JB, Liu S, Krebill R, Menard R \& Quarles LD 2010 Effects of Cinacalcet and concurrent low-dose vitamin D on FGF23 levels in ESRD. Clinical Journal of the American Society of Nephrology 5 110-116. (https://doi.org/10.2215/CJN.03630509)

Whyte MP, Teitelbaum SL, Murphy WA, Bergfeld MA \& Avioli LV 1979 Adult hypophosphatasia. Clinical, Laboratory, and Genetic
Investigation of a large kindred with review of the literature. Medicine 58 329-347. (https://doi.org/10.1097/00005792-197909000-00001)

Whyte MP, Zhang F, Wenkert D, McAlister WH, Mack KE, Benigno MC, Coburn SP, Wagy S, Griffin DM, Ericson KL, et al. 2015

Hypophosphatasia: validation and expansion of the clinical nosology for children from 25 years experience with 173 pediatric patients. Bone 75 229-239. (https://doi.org/10.1016/j.bone.2015.02.022)

Willmer T, Johnson R, Louw J \& Pheiffer C 2018 Blood-based DNA methylation biomarkers for Type 2 diabetes: potential for clinical applications. Frontiers in Endocrinology 9 744. (https://doi.org/10.3389/ fendo.2018.00744)

Wojcik M, Dolezal-Oltarzewska K, Janus D, Drozdz D, Sztefko K \& Starzyk JB 2012 FGF23 contributes to insulin sensitivity in obese adolescents - preliminary results. Clinical Endocrinology 77 537-540. (https://doi.org/10.1111/j.1365-2265.2011.04299.x)

Wu Y, Duan H, Tian X, Xu C, Wang W, Jiang W, Pang Z, Zhang D \& Tan Q 2018 Genetics of obesity traits: a bivariate genomewide association analysis. Frontiers in Genetics 9 179. (https://doi. org/10.3389/fgene.2018.00179)

Wuthier RE \& Lipscomb GF 2011 Matrix vesicles: structure, composition, formation and function in calcification. Frontiers in Bioscience $\mathbf{1 6}$ 2812-2902. (https://doi.org/10.2741/3887)

Yoshiko Y, Candeliere GA, Maeda N \& Aubin JE 2007 Osteoblast autonomous Pi regulation via Pit1 plays a role in bone mineralization. Molecular and Cellular Biology 27 4465-4474. (https://doi.org/10.1128/ MCB.00104-07)

Zhao YF, Zeng DL, Xia LG, Zhang SM, Xu LY, Jiang XQ \& Zhang FQ 2013 Osteogenic potential of bone marrow stromal cells derived from streptozotocin-induced diabetic rats. International Journal of Molecular Medicine 31 614-620. (https://doi.org/10.3892/ ijmm.2013.1227)

Zimmermann H 2006 Ectonucleotidases in the nervous system. Novartis Foundation Symposium 276 113-128; discussion 128-130, 233-117, 275-181. (https://doi.org/10.1002/9780470032244.ch10)

Received in final form 11 February 2020

Accepted 3 March 2020

Accepted Manuscript published online 3 March 2020 (c) 2020 Society for Endocrinology Published by Bioscientifica Ltd. Printed in Great Britain 